\title{
DECLENSION ERRORS IN POLISH OF BILINGUAL CHILDREN OF PRESCHOOL AGE - MULTIPLE CASE STUDY
}

\section{JUSTYNA WRONA}

\section{DECLENSION ERRORS IN POLISH OF BILINGUAL CHILDREN OF PRESCHOOL AGE - MULTIPLE CASE STUDY}

\begin{abstract}
In this paper, the inflectional errors in Polish of bilingual children were examined. My studies focus particularly on declension errors, which reflect the level of Polish grammar acquisition by pre-school bilinguals. I investigated what the level of command of the Polish declension system by bilingual children is. I also sought to determine the declension errors characteristic for the surveyed children and which case categories posed the greatest difficulty for them. The method was multiple case study. The research results show the most common types of inflectional errors made by bilingual children in the Polish language and which case categories presented the greatest challenge for them. It can be seen that inflectional errors are closely related to the second language interference, so the types of inflectional errors were predicted by L2 (different for every child). Moreover, the most challenging case categories were dative and locative. The study found that the lower the frequency of the case, the more errors associated with it were observed in the utterances of children. Such a result may indicate that cross-linguistic transfer and frequency of use are among the main factors of grammar acquisition.
\end{abstract}

KEY WORDS bilingualism, bilingual children, inflectional errors, declension errors, Polish declension system, grammar acquisition

CONTACT Pedagogical University of Krakow; justyna.wrona@doktorant.up.krakow.pl 


\section{$1 /$ INTRODUCTION}

Polish is a West Slavic language (similarly as Slovak, Czech, Kashubian and Sorbian languages) from Indo-European language family. Being an official language in the Republic of Poland and the minority language for Poles living abroad, it is used by over 45 million of speakers. The beginning of Polish as a separate language is dated at $10^{\text {th }}$ century, playing an important role in the rise of the Polish state. At first, Polish was only orally and since $12^{\text {th }}$ also written form was developed (Dunaj 2015).

The distinctive feature of Polish is strongly elaborated inflection system. Polish has three grammatical genders. The conjugation comprises the verb inflection for three persons in two numbers, three tenses (past, present and future), three moods (indicative, conditional, imperative) and two aspects (imperfective and perfective). Apart from that, the verb can be inflected for two voices - active and passive. The declension includes seven cases (nominative, genitive, dative, accusative, instrumental, locative, vocative) and two numbers (singular and plural). In Polish, nouns, adjectives, numerals, adjectival participle as well as substantive, numeral and adjective pronouns are subject to declension (Koniuszaniec - Błaszkowska 2003).

Inflectional forms are relevant when building comprehensible and correct utterances because they bring grammatical information (such as agreement or case government), providing the certain meaning (Critten et al. 2014). Additionally, as S. Montrul (2011)L2 learners have intact functional projections, but errors stem from problems during production only (a mapping or processing deficit argues, the studies of errors (e.g., inflectional errors) reflect the grammatical representation in individuals' minds. B. Mikłasz-Sendecka and O. Przybyla (2019) argue that one of the frequent difficulties of bilingual children that acquire Polish and another language at an early age is the wrong use of inflected forms, including conjugation as well as a declension of words in the Polish language. That statements show that examining inflected categories of Polish can bring relevant information about bilingual children's language development, especially in the Polish language.

There is no doubt that successful bilingual development requires rich input, and the earlier dual language acquisition will start, the more opportunities to use both languages in various communicative situations (Montrul 2011)L2 learners have intact functional projections, but errors stem from problems during production only (a mapping or processing deficit. Some researchers claim that grammar acquisition, in particular, inflection, is strongly affected by the age of acquisition because the ability to extract inflectional rules from utterances of others is decreased with age (Veríssimo et al. 2018; Bosch - Veríssimo - Clahsen 2019). J. Cieszyńska-Rożek and M. Korendo (2019) state that acquiring the declension system depends on contact with syntax schemes. The exposure to particular case categories is key to facilitating the learning process. Yet, the authors emphasize that bilingual children are 'at risk' of getting insufficient language information. What is more, J. Cieszyńska-Rożek and M. Korendo claim that the best way of effectively acquiring two languages in early childhood is to consistently use the strategy of "one person - one language" or "minority language at home".

As Pinker (1999, as cited in: Granlund et al. 2019) claims, examining the aspect of language that is inflectional morphology can bring some information about the processing and acquisition of language, and even about cognition Therefore, as in the current study, the investigation 
of declension may show us how bilingual children deal with particular cases that are relevant in effectively communicating in Polish.

\section{2 / BILINGUAL CHILDREN'S ACQUISITION OF INFLECTION FORMS}

It is commonly known that language development in a bilingual child should be dictated by the same determinants as it is acknowledged in the case of monolingual children. By and large, BFLA (Bilingual First Language Acquisition) children should achieve the same milestones as monolinguals (Hoff - Core 2013), and be able to differentiate their two languages in every aspect of the language, including morphosyntax (Serratrice 2019). Yet, despite the fact that bilingual children are within the same norms as monolinguals, practitioners can observe some individual differences in grammar acquisition (Hoff - Core 2013). These differences are also showed in research studies. F. Genesee and E. Nicoladis (2009) state that comparisons of dual and single language development in clinical conditions are relevant because they can show the meaning of the differences and can bring some practical solutions in real-world situations.

Although BFLA children are able to acquire two languages and qualitatively their language development is similar to single language development (De Houwer 2005), they process their languages differently. V. Mueller-Gathercole (2002) tried to examine what differences can be observed while testing English-Spanish children in elementary school with a focus on these aspects of L1 grammar that are absent in L2 grammar. The researcher designed studies probing the use of such structures as the mass/count noun distinction in quantification structures and grammatical gender. The first one is present in English, not in Spanish, while the second one is distinguished in Spanish, not in English. One of the most important conclusions of this research was that the bilinguals that were learning L2 at school had lower scores than bilinguals who learned two languages through a bilingual background, and that group had lower scores in comparison to monolinguals.

M. Polinsky (2006) suggests that errors in the early stages of bilingual development are normative, as well as errors made by child L1 learners. Yet, his research shows that bilingual children tend to make persistent errors (like adult L2 learners), especially in heritage language (the language of minority). What is significant, the case marking system is one of the most sensitive parts of grammar for dual acquisition. M. Polinsky claims that Russian heritage speakers mostly use only two out of six grammar cases.

The differences between bilingual and monolingual children were also investigated during B. Z. Pearson's (2002) research. Groups of Spanish-English students and English students from elementary schools in Miami took part in this study. It turned out that in a story-telling task, the bilinguals were worse in morphology and syntax than monolinguals. Yet, the differences were not large, so it is likely that more extensive contact with languages could have provided better language skills and decreased the differences. Nevertheless, these result suggests that bilingual children can have some delay in grammar acquisition.

On the other hand, research conducted by J. Paradis (2010) shows that English-French speaking children have the same level of verb morphology as their monolingual peers. Yet, as the researcher supposes, this result may stem from the fact of the high status of both English and 
French in Canada (where the study was conducted). It is also possible that the similar levels of bilinguals and monolinguals in this research and differences between those groups in Mueller-Gathercole's study (2002) result from the fact of probing the verb inflection, whilst the noun morphology may be more complicated and differential between languages.

Beyond the status of languages, the relevant factor influencing the differences between bilingual and monolingual in grammar acquisition is the similarity between the languages. A. Zawiszewski and I. Laka (2020) compared Spanish and Basque speakers by testing declension categories present in L1 and L2 and categories found only in one of the languages. The results showed that there were fewer errors in categories occurring in both languages, and therefore it was noticeable that even for early bilinguals L2 is highly modulated by L1. These results are connected with a positive transfer, that is when the similarities between both languages facilitate the acquisition. Moreover, the transfer occurs in both directions, we can use the structures from L1 to communicate in L2, but we can also transmit the L2 grammar aspects to L1. On the other hand, the cross-linguistic transfer can be negative and the reason for some errors in one of the languages (Wodniecka et al. 2018). E. Nicoladis (2003) found that the cross-linguistic transfer takes place especially in productive skills, and this does not influence comprehension. Additionally, E. Nicoladis' analysis reveals that the transfer occurs particularly when children acquire ambiguous language andwhen the features of the languages are varied.

\section{3 / THE POLISH DECLENSION SYSTEM AND ITS ACQUISITION}

The present study is highly related to the Polish declension system. As E. Dąbrowska and M. Szczerbiński (2006) emphasize, Polish is a highly inflectional language with an elaborate declension system. There are seven grammatical cases in Polish; each distinguishes itself through several different endings. The choice of the ending of a particular case is predicted by gender (masculine, feminine, neuter) or phonological aspects (when there are more endings of a case for one gender) (Dąbrowska - Szczerbiński 2006). They are used in different grammar contexts, and they condition the meaning and logical order of the utterance. The cases are presented in Table 1.

Table 1. The Polish grammatical cases, their endings in singular forms, and their main uses

\begin{tabular}{|c|c|c|c|c|}
\hline Case & $\begin{array}{l}\text { Endings for } \\
\text { masculine }\end{array}$ & $\begin{array}{l}\text { Endings for } \\
\text { feminine }\end{array}$ & $\begin{array}{l}\text { Endings for } \\
\text { neuter }\end{array}$ & Main uses \\
\hline Nominative & $-a(-\varnothing,-i)$ & $-\varnothing(-a,-o)$ & $-0,-e,-e$ & $\begin{array}{l}\text { citation form; subject; subject } \\
\text { predicative; when addressing } \\
\text { a person }\end{array}$ \\
\hline Genitive & $-i /-y$ & $-a,-u(-i /-y)$ & $-a$ & $\begin{array}{l}\text { adnominal modifier (e.g. pos- } \\
\text { sessor); partitive; after negated } \\
\text { verbs and after nie ma ('not have') } \\
\text { to indicate absence; with certain } \\
\text { verbs and prepositions }\end{array}$ \\
\hline Dative & -'e, -i/-y & $\begin{array}{l}\text {-owi (-u, -'e, } \\
-i /-y)\end{array}$ & $-u$ & $\begin{array}{l}\text { indirect object (addressee, } \\
\text { recipient); beneficiary; experi- } \\
\text { encer; with certain verbs and } \\
\text { prepositions }\end{array}$ \\
\hline
\end{tabular}




\begin{tabular}{|c|c|c|c|c|}
\hline Accusative & $-\mathrm{e}(-\varnothing)$ & $-\varnothing,-a\left(-e_{c},-0\right)$ & $=\mathrm{NOM}$ & $\begin{array}{l}\text { direct object (patient, theme); } \\
\text { with certain prepositions }\end{array}$ \\
\hline $\begin{array}{l}\text { Instrumen- } \\
\text { tal }\end{array}$ & $-a ̨$ & $-\operatorname{em}(-a)$ & -em & $\begin{array}{l}\text { instrument; subject predicative; } \\
\text { with certain verbs and prepo- } \\
\text { sitions }\end{array}$ \\
\hline Locative & $-' e,-i /-y$ & -'e, -u (-i/-y) & $-' e,-u$ & with certain prepositions \\
\hline Vocative & $-0,-u,-i /-y,(-\varnothing)$ & -'e, -u, (-o) & $-0,-e,-e ̨$ & $\begin{array}{l}\text { when addressing a person; } \\
\text { sometimes as subject }\end{array}$ \\
\hline
\end{tabular}

Source: Table compiled from Table 1 and Table 2 in Dąbrowska, Szczerbiński 2006, p. 562

S. Granlund and colleagues' (2019) analysis reveals that the acquisition of the Polish inflectional system is strongly affected by token frequency and phonological neighborhood density. The first one means that the greater frequency of a particular declension form, the better the production and recognition of this form. The second effect is that the greater the number of similar words in basic forms and in target forms (e.g., with the same endings like lalka 'doll' (nominative-word) - lalce (dative form), czapka 'cap' (nominative-word) - czapce (dative form), the better the production and recognition of that form. E. Dąbrowska and M. Szczerbiński (2006) argue that token frequency is especially observed in younger children's (two- and three-years old) utterances, while phonological density is distinctive for older children and adults.

E. Łuczyński (2002) states that in Polish children, the development of noun inflection begins with mastering the three most functional cases, such as: nominative, accusative, and vocative. The factor that strengthens this order in speech ontogenesis is the fact that at present the nominative form is very often used in the role of all three cases. The next instances of a noun appearing in the child's speech are genitive, instrumental, locative, and dative. E. Łuczyński (2010) emphasized that two-year-old children are capable of using most of the inflectional forms. This statement is compliant with E. Dąbrowska and M. Szczerbiński's analysis, which showed that two-year-old children could use most of the cases correctly, apart from dative neuter. Moreover, four-year-old children have the ability to use all cases, similarly to adults (Dąbrowska Szczerbiński 2006). The genitive acquisition may be a proof of this - in the masculine nouns the declension is irregular and in the female nouns the endings are regular but both patterns are developed in paralell. It should also be added that in the contemporary Polish language, we can observe the extended use of the genitive case (this case has become multifunctional and is compacted in different contexts) and the calibration margin of the vocative paradigm (Euczyński 2010). As the vocative form is considered peripheral and rarely used even by adult speakers of the Polish language, it has not been included in the research presented in this paper.

\section{4 / THEORETICAL AND METHODOLOGICAL BASES FOR THE PRESENT RESEARCH ANALYSIS}

The starting point for the analysis of the utterances of bilingual children was the classification developed by A. Dąbrowska and M. Pasieka (2008). These authors have developed a fairly detailed typology of language mistakes made by people learning Polish as a foreign language. Namely, they distinguished four groups of errors: form, use, lexical and stylistic, assigning 
specific categories and subcategories of errors made by foreigners to each of them. To analyze the language material, the selected types of errors identified by A. Dąbrowska and M. Pasieka were adopted. These are some form errors in terms of inflection. The categories of errors noted by the author of this study were also added to these types of errors. Table 2 presents this specific typology, which was used to analyze the statements of bilingual children.

Table 2. Typology of errors for the analysis of the linguistic material collected during the research (types of errors in italics were developed by the author of this study)

\begin{tabular}{ll}
\hline Group of linguistic errors & Categories and subcategories of language errors \\
\hline Form errors & 1. Inflection \\
& 1.1 Noun declension \\
& 1.1.1 Selecting the wrong parallel desinence \\
& 1.1.2 Incorrect stem alternations \\
& 1.1.3 No declension \\
& 1.1.4 Wrong case selection \\
& 1.1.5 Choosing a desinence beyond the flection paradigm \\
& (changing the grammatical gender) \\
\hline
\end{tabular}

Source: Adaptation of typology of errors based on Dąbrowska - Pasieka 2008.

The aim of this research was to check how the studied children deal with noun declension in Polish - the significant part of grammar that determines effective communication and reflects the level of Polish language acquisition. Therefore, the following general research question was posed: What is the level of mastering the noun inflection of the Polish language in bilingual children? There were also formulated two specific questions: What inflectional errors do the studied children make? Which case categories are the most difficult for them?

\section{5 / METHOD}

\section{1 / Participants}

Four bilingual pre-school children (age from 3;7 to 4;8) took part in this study. The children were in the same kindergarten group. Two of the participants were girls, and two were boys. All the children were early bilingual (they started their second language acquisition before the age of three), but they used different strategies to acquire the two languages (the strategy of person or the strategy of place). An important factor is that there was a significant difference between the studied children in linguistic competence levels in the Polish language. The children's names were changed for the purpose of this study.

Bianca $(3 ; 7)$ was born in Poland and was raised speaking two languages - Spanish and Polish, from birth. The girl speaks Polish better, but - as her parents point out - the difference between the knowledge of the languages is small. The child speaks Spanish to her mother and Polish to her father. Therefore, the girl learns both languages from an early age according to the person's strategy. Bianca presents classical simultaneous bilingualism yet at the same time unbalanced, which is natural due to the child's permanent residence. According to her parents, the girl sometimes mixes the languages, but this does not cause any major communication problems. Overall, Bianca is able to adapt her language to the interlocutor. 
Stefania $(3 ; 10)$ is a bilingual child raised by a Polish mother and an Italian father. She was born in Poland and she lives there permanently. From birth, the girl was raised speaking two languages (Italian and Polish), so it can be said that Stefania presents simultaneous bilingualism, although - as the parents admit - unbalanced. The girl speaks Polish better, but she can also communicate in Italian with family members. The parents consistently use the person's strategy, thanks to which the girl can easily adapt her language to the interlocutor. However, she sometimes mixes codes, creates neologisms, and builds Polish words based on Italian words. The parents also point out that Stefania has a worse vocabulary than her peers, confuses tenses, and builds incorrect verb forms (e.g., ją instead jedzą ('they eat'), or możem instead moge ('I can') - examples provided by the parents).

Milan (4;0) is of Hungarian origin. He was born in Great Britain but moved to Poland when he was two-year-old. He started going to kindergarten before the age of three. The boy then began to acquire Polish according to the strategy of the place. Milan presents simultaneous bilingualism because the second language acquisition started before his first language, i.e., Hungarian, was thoroughly mastered. The boy is not bilingual in a balanced way - he speaks Hungarian better. According to the parents, the child often mixes languages (Polish and Hungarian).

Adam $(4 ; 8)$ is a boy raised by a Polish-speaking mother and an English-speaking father. The child was born and still lives in Poland. He has been going to kindergarten for two years. In Adam's case, the parents did not apply the person's strategy consistently - both parents used English more willingly. Adam speaks English better due to this fact, so he is simultaneously but not balanced bilingual. Currently, the mother is working on the child's Polish, although she still speaks English with her son. On the other hand, a father who learns Polish as a foreign language communicates with the child in Polish in some situations. According to the parents, the child often mixes the languages. When he does not know Polish words, he interlards words from English or makes up his own words. It happens that the boy starts to get lost in speaking Polish and, as a result, switches to English.

\section{2 / Procedure}

The research method was a multiple case study. A case study approach was used to allow for the application of three techniques useful in this research. The primary research technique was the analysis of the transcribed children's statements, which can be classified as a technique called document analysis. The second technique was an interview with the teacher of the kindergarten group that the children attended. The interview was structured and served mainly to supplement the information on the examined children. The third technique was a questionnaire addressed to the parents of the preschoolers participating in the study. Similar to the interview, the survey was designed to obtain further information about the children.

The study took place at the end of 2018 and was divided into three stages. The first step was to interview the kindergarten teacher to obtain the necessary information on the family situation of the children, functioning in the kindergarten and at home, and their language competences from the perspective of growing up speaking two languages. This interview was also the basis for preparing the research part in which the children participated. 
The second and main stage of the study was the performance of specific tasks by the children. The first was to describe an illustration taken from "The Great Book of Golden Fairy Tales" (1997) by the participants. The picture shown to the children was one of the fairy tale scenes about the ugly duckling. Then, the researcher asked the children questions related to the illustrations, at the same time checking the occurrence of a given inflectional category in the child's language.

The second task was a bit more elaborate. Initially, it consisted of a question-driven conversation, which - as in the case of illustrations - was to establish the ability to inflect words by appropriate cases. This conversation concerned three pictures that make up a picture story. Then the children composed a story and talked about what happened in the pictures. The study used four picture stories published by Harmonia (2009). Each time the child's workflow with a picture story was similar. It is worth mentioning that most of the children did not compose all the stories in one day (the exception was one girl, whose level of concentration was so high that she completed all tasks on the same day). The study with the children was conducted individually and took place in a separate room at the kindergarten. All children's utterances and researcher's instructions/questions were recorded by dictating machine. Then, the collected voice material was transcribed. The researcher conducted the qualitative analysis of transcribed statements, noting the inflectional forms for each child separately. The presented data in tables in 'Results' section come from both sets of tasks (guided discourse about the illustration and story-telling).

The third stage of the study was the distribution of questionnaires among the parents of the four bilingual children. This part of the research was intended to complement the information obtained earlier from the teacher and from the observations of the studied children. It should be noted that, as requested, the parents completed the questionnaires by answering all questions.

\section{6 / RESULTS}

\section{1 / Bianca}

Research shows that Bianca's greatest difficulty was choosing the right case. Other types of errors appeared sporadically. The numerical list of errors presented in Table 3 shows that the girl made few mistakes.

Table 3. Types of inflectional errors made by Bianca regarding the declension of the noun

\begin{tabular}{ll}
\hline Types of declension errors & Number of errors \\
\hline Wrong case selection & 10 \\
\hline No declension & 1 \\
\hline $\begin{array}{l}\text { Choosing a desinence beyond the flection paradigm } \\
\text { (changing the grammatical gender) }\end{array}$ & 1 \\
\hline Incorrect stem alternations & 1 \\
\hline Selecting the wrong parallel desinence & 1 \\
\hline
\end{tabular}

Source: Own study 
Research shows that Bianca's greatest difficulty was with the dative case. The second case in which the girl made the most mistakes (statistically) was the locative case. The few errors in the accusative and instrumental forms prove that the child had no major difficulties with them. It is worth noting that Bianca did not make any mistakes regarding the use of the genitive case. This category turned out to be the easiest to use for the girl. Detailed data are presented in Table 4.

Table 4. Errors made by Bianca in each case category

\begin{tabular}{llll}
\hline Case & All words & Incorrect words & Errors on average \\
\hline dative & 11 & 6 & $55 \%$ \\
\hline locative & 23 & 3 & $13 \%$ \\
\hline accusative & 35 & 4 & $11 \%$ \\
\hline instrumental & 13 & 1 & $8 \%$ \\
\hline genitive & 12 & 0 & $0 \%$ \\
\hline
\end{tabular}

Source: Own study

Bianca made a small number of errors, which proves that the Polish language's inflection is not a major problem for her. The child mastered the correct forms of the declension, and now some of them still need to be consolidated.

\section{2 / Stefania}

Undoubtedly, the most common mistake made by Stefania regarding the declension was selecting the wrong parallel desinence. These errors usually appeared in the case of masculine non-life words (e.g., ogniu ('fire') instead of ognia ('of fire'). Relatively often, the girl made erroneous alternations within the stem. In the feminine gender, the girl did not exchange consonants, which resulted in the appearance of such forms of words as: dziewczynke instead of dziewczynce ('to girl'), miske ('bowl') instead of misce ('to bowl'). There were also significant errors in inanimate masculine nouns - the girl did not replace the hard consonant with the soft consonant, so, for example, we noticed such forms as $w$ lasu instead of $w$ lesie ('in the forest') (additionally, there was no vowel alternation a:e).

Stefania also chose the wrong forms of cases or did not inflect the nouns. The child did not make mistakes of choosing a desinence beyond the declension paradigm that would result in a change of noun gender. Detailed data are presented in Table 5.

Table 5. Types of inflectional errors made by Stefania regarding the declension of the noun

\begin{tabular}{ll}
\hline Types of declension errors & Number of errors \\
\hline Selecting the wrong parallel desinence & 7 \\
\hline Incorrect stem alternations & 6 \\
\hline Wrong case selection & 5 \\
\hline No declension & 3 \\
\hline $\begin{array}{l}\text { Choosing a desinence beyond the flection paradigm } \\
\text { (changing the grammatical gender) }\end{array}$ & 0 \\
\hline
\end{tabular}

Source: Own study 
Overall, the girl made fairly few mistakes, but they were noticeable in every case category tested in the studies. The dative case was the most difficult for Stefania, which also appeared the least frequently in the child's statements. There were also a lot of errors regarding the locative case. The girl most often used the accusative and had the fewest problems with this case. Stefania also used the genitive and instrumental forms with a small number of errors. Detailed data are presented in Table 6.

Table 6. Errors made by Stefania in each case category

\begin{tabular}{llll}
\hline Case & All words & Incorrect words & Errors on average \\
\hline dative & 9 & 4 & $44 \%$ \\
\hline locative & 32 & 7 & $22 \%$ \\
\hline genitive & 24 & 4 & $17 \%$ \\
\hline instrumental & 17 & 1 & $6 \%$ \\
\hline accusative & 55 & 3 & $5 \%$ \\
\hline & & Source: Own study
\end{tabular}

In summary, these results show that Stefania knew the Polish declension rules, and she did not have any serious problems with inflection.

\section{3 / Milan}

The research shows that the boy mostly did not decline words. The greatest difficulty for Milan, therefore, was the declension and the choice of any inflectional ending. The second most frequent mistake was adding an inflectional ending, which does not belong to the declension paradigm, which resulted in a change in the grammatical gender of a given word. This error manifested itself in the inflection of masculine and neuter words - they were inflected according to the feminine paradigm. This phenomenon was quite regular in the boy's statements. The following examples illustrate this: Czym bawi się chłopiec? Milan: Samolota instead of Samolotem ('What is the boy playing with?' Milan: 'With plane'); Komu przyglada sie dziewczynka? Milan: Kaczątce instead of Kaczątku. ('Who is the girl looking at?' Milan: Duckling'); Na czym stoi kaczątko? $\mathrm{Na}$ stolikq instead of $\mathrm{Na}$ stoliku ('What is the duckling standing on?' Milan: 'On the table.' Milan also made an occasional wrong case selection. Detailed data are presented in Table 7.

Table 7. Types of inflectional errors made by Milan regarding the declension of the noun

\begin{tabular}{ll}
\hline Types of declension errors & Number of errors \\
\hline No declension & 42 \\
\hline $\begin{array}{l}\text { Choosing a desinence beyond the flection paradigm } \\
\text { (changing the grammatical gender) }\end{array}$ & 15 \\
\hline Wrong case selection & 2 \\
\hline Incorrect stem alternations & 0 \\
\hline Selecting the wrong parallel desinence & 0 \\
\hline
\end{tabular}

Source: Own study 
The most difficult case category for Milan was dative. Nearly all the words that should be declined by this case were incorrect. The boy also made numerous mistakes in the forms of the locative, instrumental, and accusative. Research also shows that Milan used the genitive case best. Detailed information is presented in Table 8.

Table 8. Errors made by Milan in each case category

\begin{tabular}{llll}
\hline Case & All words & Incorrect words & Errors on average \\
\hline dative & 10 & 9 & $90 \%$ \\
\hline locative & 17 & 13 & $76 \%$ \\
\hline instrumental & 14 & 10 & $71 \%$ \\
\hline accusative & 30 & 20 & $67 \%$ \\
\hline genitive & 11 & 7 & $64 \%$ \\
\hline & & Source: Own study
\end{tabular}

Overall, these results indicate that Milan made many inflectional errors when it came to the noun. He did not decline most of the words. According to the feminine inflection paradigm, a phenomenon characteristic of Milan's statements was also the inflection of words.

\section{4 / Adam}

According to his parents and the teacher, Adam has problems with Polish grammar, making his statements incoherent, chaotic, and difficult to understand. The research somewhat confirms these opinions. The greatest difficulty in terms of noun inflection is the lack of word declension, which is most likely the result of English interference. The child did not use appropriate case endings, confused individual inflectional forms, and used them inadequately to the situation, which sometimes changed the meaning of the statement. The child also built words using desinence that went beyond the paradigm of declension. This phenomenon is illustrated in such examples as: Co dziewczynka trzyma w ręce? Adam: Kubeczkę instead of Kubeczek ('What is the girl holding in her hand?' Adam: 'A cup'); $Z$ czym dziewczynka je kanapkę? Adam: $Z$ szynkiem instead of $Z$ szynkq ('What does the girl eat a sandwich with?' Adam: 'With ham'). These errors indicate that the child was changing the gender of the pronounced noun. Adam also made mistakes regarding alternations within the stem. A parallel desinence error was noticed only once. The list of inflectional errors made by the boy is presented in Table 9.

Table 9. Types of inflectional errors made by Adam regarding the declension of the noun

\begin{tabular}{ll}
\hline Types of declension errors & Number of errors \\
\hline No declension & 46 \\
\hline Wrong case selection & 15 \\
\hline $\begin{array}{l}\text { Choosing a desinence beyond the flection paradigm } \\
\text { (changing the grammatical gender) }\end{array}$ & 5 \\
\hline Incorrect stem alternations & 2 \\
\hline Selecting the wrong parallel desinence & 1 \\
\hline
\end{tabular}

Source: Own study 
Research shows that Adam made numerous mistakes in all the tested case categories. The biggest problems for the child were the dative and locative case. A lot of errors also appeared in the instrumental and genitive forms. The boy was the least bothered by accusative forms. Detailed data are presented in Table 10.

Table 10. Errors made by Adam in each case category

\begin{tabular}{llll}
\hline Case & All words & Incorrect words & Errors on average \\
\hline dative & 9 & 8 & $89 \%$ \\
\hline locative & 21 & 18 & $86 \%$ \\
\hline instrumental & 21 & 14 & $67 \%$ \\
\hline genitive & 16 & 8 & $50 \%$ \\
\hline accusative & 40 & 19 & $48 \%$ \\
\hline \multicolumn{4}{c}{ Source: Own study }
\end{tabular}

To sum up, these results suggest that Adam has a lot of trouble using Polish declension. He makes numerous mistakes, mainly due to the lack of declension. These errors make it much more difficult for the child to communicate effectively.

\section{7 / DISCUSSION}

The results show that the errors connected with cases reflect the speech ontogeny of Polish children, and they are predicted by frequency. It is consistent with previous studies of the acquisition of the Polish inflectional system (Dąbrowska - Szczerbiński 2006; Granlund et al. 2019). While the most difficult grammatical cases for bilingual children are locative, and dative and the best-acquired cases are accusative and genitive, distinguishing with high frequency in the Polish language. On the other hand, the cross-linguistic transfer seems to be the key factor of inflectional errors. The negative transfer (a reason for errors in one of the languages, as Wodniecka et al. (2018) suggest) was noticeable in each child's case.

For Bianca (Polish-Spanish girl) and Stefania (Polish-Italian girl), the most typical errors involved wrong case selection, choice of the wrong parallel desinence, and incorrect stem alternations. The second language of both girls is a Romanic language - Spanish or Italian - and it is possible that some features of these languages predict the detected errors. Firstly, there is no declension, which consists in changing the stem and inflectional ending. Secondly, in Italian or Spanish, an appropriate preposition indicates a grammatical case.

For Milan (Hungarian-Polish), the most characteristic error was no declension and choice of a desinence beyond the flection paradigm (and as a result, the boy was changing the grammatical gender). Declension in Hungarian depends on adding the equivalent of the Polish preposition, and it might be the reason for no declension in Milan's Polish. The probable explanation for choosing a desinence beyond the flectional paradigm is that there is no gender in Hungarian. The boy had a problem with identifying the gender and selecting the right endings, but he used the correct grammatical case.

Adam (English-Polish) often used only basic forms, and he did not decline the nouns (no declension was the frequent type of noticed errors). He also had difficulties in choosing 
the appropriate case, and he chose the desinences beyond the flection paradigm (changing the grammatical gender). The probable reason for all the errors made by the boy is that English is not an inflectional language, and there is hardly any gender in English.

All in all, the analysis confirmed the phenomena of cross-linguistic transfer (see Zawiszewski - Laka 2020). The results showed a relationship between transfer and the diversity of the languages. As was investigated in the previous study (Nicoladis 2003), the differences between languages were predictors of transfer appearing. Findings from utterances of Milan and Adam are consistent with the previous study in which the researcher investigated that Estonian-English child preferred basic forms, and this was particularly noticeable in Estonian, the inflected language (Vihman 1982). Additionally, the study found that children had no serious difficulties in comprehending the statements of the researcher. The conclusion is that every child is able to understand the Polish declined words, but they struggle with grammatical cases while speaking. This result is in line with E. Nicoladis' analysis (2003), which revealed that transfer is more noticeable in productive skills than receptive skills.

Although bilingual children are able to acquire all grammatical cases in Polish like their monolingual peers (which confirms the statement of L. Serratrice (2019) that bilingual children can learn languages at a similar level as their monolingual peers), it seems that processing of two languages can inhibit the acquisition of the declension system in Polish (see Mikłasz-Sendecka - Przybyla 2019) and this is conditioned by the quality of contact with Polish and the strategy of language acquisition (see Cieszyńska-Rożek - Korendo 2019). Probably, the most effective way to learn a language is one person - one language. The strategy of place (the second strategy of acquiring the language by some of the studied children) seems to bring smaller effects. That assumption is consistent with J. Cieszyńska and M. Korendo's view (2019) that one of the best way of acquiring two languages is "one person - one language" strategy.

\section{8 / CONCLUSION}

The present study was designed to determine the acquisition of the Polish marking system by bilingual children of pre-school age. The specific aim of this research was to investigate what kind of inflectional errors bilingual children make and which case categories are the most difficult for them.

The study found that, in general, bilingual children are able to acquire the declension system following the same path as their monolingual peers, but they make specific kinds of errors that probably show the effect of the cross-linguistic transfer. The type of the most frequent errors was different for every child, which shows that the nature of the second language is the key factor in mastering the declension system, and the transfer can delay the acquisition of the Polish marking system. It is worth to mention that in the speech of Polish monolingual children, you can also find incorrect grammatical forms, nevertheless they occur with less intensity and frequency, or have a different background than in the case of bilingual children (there are no interference results from the child's second language).

The results reveal that children who use languages where specific cases are determined by the use of appropriate prepositions, make peculiar combinations, and although there are errors, children struggle with linguistic interference and show that they understand the 
necessity to use a form other than the nominative. Research suggests that the most difficult thing is to master the inflection of the Polish language for those children whose second language does not distinguish the grammatical cases. An additional difficulty in mastering inflection may be hardly ever distinguishing between gender in second languages. Taking into account that some bilingual children make relatively few grammatical errors, it can be predicted that they will stop using inappropriate inflectional forms with progressive cognitive development and schooling in Polish system of education. It can be also assumed that bilingual children who make numerous mistakes that make their speech agrammatical will need linguistic support (e.g. additional classes in Polish as a second language).

The research also provides some premises that may be useful during speech therapy classes or Polish as a foreign/second language lessons with the participation of bilingual children. The results reveal that the most difficult grammatical cases for each child were dative and locative so it could be also the most difficult case category for bilinguals/foreigners learning Polish in general. On the other hand, the easiest for children were accusative, genitive and instrumental.

Above observation is connected with another significant finding was that the greater the frequency of the grammatical cases, the easier they were for the children. It is highly probable that this result is related to children's natural acquisition of the Polish language and extraction of the declension rules from daily communication (in which genitive and accusative are dominant). The study has also shown that the difficulties with grammatical cases appear, in particular, while speaking in Polish, but not during the comprehension of Polish. Imperfect declension mastery translates into productive skills - speaking and, probably, writing in the future. The empirical findings in this study provide a deeper understanding of the acquisition of inflectional language such as Polish and present likely phenomena regarding other Slavic languages.

\section{DECLENSION ERRORS IN POLISH OF BILINGUAL CHILDREN OF PRESCHOOL AGE - MULTIPLE CASE STUDY}

SUMMARY In this paper I am researching acquisition of grammar skills in Polish (with particular emphasis on declension) of bilingual children whose one of the languages is Polish. I refer to research on language development in children Polish-speaking (Dąbrowska - Szczerbiński 2006; Łuczyński 2002; Łuczyński 2010) to $4 ; 8$ and 16 adult controls participated in a nonce-word inflection experiment testing their ability to use the genitive, dative and accusative inflections productively. Results show that this ability develops early: the majority of two-year-olds were already productive with all inflections apart from dative neuter; and the overall performance of the four-year-olds was very similar to that of adults. All age groups were more productive with inflections that apply to large and/or phonologically diverse classes, although class size and token frequency appeared to be more important for younger children (two- and three-year-olds). After analyzing the literature on the subject, I wanted to find answers to the questions of what inflectional errors are characteristic for the surveyed children and which categories of the case poses the greatest difficulty for them. 
The research method was qualitative - multiple case study. In the study participated four children. Each child knew Polish and a second language: Spanish, Italian, English or Hungarian. The research results show what types of inflection errors are the most common for bilingual children and which case categories are for them the greatest challenge. It turned out that the greater frequency of the case, the fewer errors associated with it were observed in utterances of children. Moreover, it can be seen that inflectional errors are closely related with second language interference. The results support the thesis that languages they interpenetrate and create a specific language system (Wodniecka et al. 2018).

\section{REFERENCES}

I 3-elementowe historyjki obrazkowe [3-element picture stories], 2009, Gdańsk.

I Bosch S. - Veríssimo J. - Clahsen H., 2019, Inflectional morphology in bilingual language processing: An age-of-acquisition study, Language Acquisition, 26(3), 339-360.

I Busquets C. (il.), 1997, Wielka Ksiega Złotych Bajek [The Great Book of Golden Fairy Tales], Zielona Góra.

I Cieszyńska-Rożek J. - Korendo M., 2019, Stymulacja rozwoju dzieci dwujęzycznych. Metoda Krakowska [Stimulating the Development of Bilingual Children. The Krakow Method], Pismo Federalnego Związku Nauczycieli Języka Polskiego, 40(7), 40-47.

I Critten S. - Connelly V. - Dockrell J. E. - Walter K., 2014, Inflectional and derivational morphological spelling abilities of children with Specific Language Impairment, Frontiers in Psychology, 5, pp. 948.

I Dąbrowska A. - Pasieka M., 2008, Nowa typologia błędów popełnianych przez cudzoziemców w języku polskim [A new typology of mistakes made by foreigners in Polish], Błąd językowy w perspektywie komunikacyjnej, ed. M. Kita, Katowice, 73-102.

I Dąbrowska E. - Szczerbiński M., 2006, Polish children's productivity with case marking: The role of regularity, type frequency, and phonological diversity, Journal of Child Language, 33(3), 559-597.

I De Houwer A., 2005, Early bilingual acquisition: Focus on morphosyntax and the separate development hypothesis, The handbook of bilingualism, eds. J. Kroll, A. De Groot, Oxford, pp. 30-48.

I Dunaj B., 2015, Zwięzła historia języka polskiego-założenia opisu, Poznańskie Studia Polonistyczne. Seria Językoznawcza, 22 (42), 69-79.

I Genesee F. - Nicoladis E., 2009, Bilingual first language acquisition, Blackwell handbook of language development, eds. E. Hoff, Marilyn Shatz, Chichester, pp. 324-342.

I Granlund S. - Kolak J. - Vihman V. - Engelmann F. - Lieven E. V. M. - Pine J. M. Theakston A. L. - Ambridge B., 2019, Language-general and language-specific phenomena in the acquisition of inflectional noun morphology: A cross-linguistic elicited-production study of Polish, Finnish and Estonian, Journal of Memory and Language, 107, pp. 169-194.

I Hoff E. - Core C., 2013, Input and Language Development in Bilingually Developing Children, Semin Speech Language, 34 (4), pp. 215-226.

I Koniuszaniec G. - Błaszkowska H., 2003, Language and gender in Polish, Gender Across Languages: The linguistic representation of women and men, ed. M. Hellinger, H. Bußmann, 259-285. 
I Łuczyński E., 2002, Fleksja języka polskiego z punktu widzenia ontogenezy mowy [Polish Inflection From The Point Of Speech Ontogenesis' View], Biuletyn Polskiego Towarzystwa Językoznawczego, LVIII, pp. 157-166.

I Łuczyński E., 2010, Akwizycja gramatyki jezyka polskiego [Polish Grammar Acquisition], Psychologia rozwojowa, 15 (1), 9-18.

I Mikłasz-Sendecka B. - Przybyla O., 2019, Dwujęzyczność wczesnodziecięca - Studium przypadku [Early Childhood Bilingualism - A Case Study], Logopedia Silesiana, 8, pp. 461-486.

I Montrul S., 2011, Morphological errors in Spanish second language learners and heritage speakers, Studies in Second Language Acquisition, 33 (2), 163-192.

I Mueller Gathercole V. C., 2002, Command of the Mass/Count Distinction in Bilingual and Monolingual Children: An English Morphosyntactic Distinction, Language and Literacy in Bilingual Children, eds. K. Oller, R. Eilers, pp. 175-206.

I Nicoladis E., 2003, Cross-linguistic transfer in deverbal compounds of pre-school bilingual children, Bilingualism, 6 (1), pp. 17-31.

I Paradis J., 2010, Bilingual children's acquisition of English verb morphology: Effects of language exposure, structure complexity, and task type, Language Learning, 60 (3), pp. 651-680.

I Polinsky M., 2006, Incomplete Acquisition: American Russian, Journal of Slavic Linguistics, 14 (2), pp. 191-262.

I Serratrice L., 2019, Becoming Bilingual in Early Childhood, The Cambridge Handbook of Bilingualism, eds. A. De Houwer \& L. Ortega, Cambridge pp.15-35.

I Veríssimo J. - Heyer V. - Jacob G. - Clahsen H., 2018, Selective Effects of Age of Acquisition on Morphological Priming: Evidence for a Sensitive Period, Language Acquisition, 25 (3), pp. 315-326.

I Vihman, M., 1982, The acquisition of morphology by a bilingual child: A whole-word approach, Applied Psycholinguistics, 3 (2), pp. 141-160.

I Wodniecka Z. - Mieszkowska K. - Durlik J. - Haman E., 2018, Kiedy $1+1 \neq 2$, czyli jak dwujęzyczni przyswajają i przetwarzają język(i) [When $1+1 \neq 2$, i.e. How Bilingual People Assimilate and Process Language(s)], Logopedia międzykulturowa, ed. E. Czaplewska, Gdańsk, pp. 92-131.

I Zawiszewski A. - Laka I., 2020, Bilinguals processing noun morphology: Evidence for the Language Distance Hypothesis from event-related potentials, Journal of Neurolinguistics, 55, pp. 100908

I Pearson Z. B., 2002, Narrative Competence among Monolingual and Bilingual School Children in Miami, Language and Literacy in Bilingual Children, eds. D. K. Oller, R. Eilers, Clevedon, pp.135-74. 